\title{
EVALUASI PENGGUNAAN OBAT GASTRITIS PADA PASIEN RAWAT INAP DI RS GRANDMED LUBUK PAKAM TAHUN 2020
}

\section{DINI MAYASARI ${ }^{1}$, DELFI MUTIARA ${ }^{2}$, DEBI DINHA OCTORA ${ }^{3}$}

\author{
INSTITUT KESEHATAN MDISTRA LUBUK PAKAM \\ Jl. Sudirman No.38, Petapahan, Kec. Lubuk Pakam, Kab. Deli Serdang, \\ Sumatera Utara \\ e-mail: mayasaridini138@gmail.com \\ DOI : https://doi.org/10.35451/jfm.v4i1.577
}

\begin{abstract}
Gastritis is a disease caused by the bacterium Helicobacter phylory, this first gastritis drug, namely Antacids, Omeprazole, and Ranitidine. The increasing number of Gastritis patients from 2019 to 2020 at Grandmed Lubuk Pakam Hospital is encouraging researchers to conduct this study. The purpose of this study was to determine the description of the use of Gastritis drugs and the rationality of the use of Gastritis medications in Gastritis patients at Grandmed Lubuk Pakam Hospital in 2019. This study was a descriptive (non-experimental) study with retrospective data collection taken from patient medical records. Gastritis at Grandmed Lubuk Pakam Hospital. Data were collected using a purposive sampling technique in accordance with the inclusion criteria and exclusion criteria using the Data Collection Sheet. The number of samples used in this study were 64 medical records of patients diagnosed with gastritis. Data analysis was performed using Univariat with the help of SPSS. Results of distribution of duration of treatment data for which most patients undergo treatment. And the number of Chronic Diseases suffered by Diarrhea patients is 20 patients (31.2\%). All three have a significant relationship with patient care outcomes. While in the age range 31-60 years, 45 people (70.3\%) affected by gastritis. and The results of evaluating the rationality of treatment for gastritis are the right indications (96.9\%), (62 patients), 100\% correct patients (64 patients), the right medication by (96.9\%) (62 patients), and the correct dosage $100 \%$ correct (64).
\end{abstract}

Key words : RS Grandmed Lubuk Pakam, Medicine Gastritis.s 


\section{PENDAHULUAN}

Kesehatan merupakan masalah yang harus diperhatikan oleh setiap makhluk hidup khususnya manusia. Kesehatan menjadi hal yang sangat perlu diperhatikan khususnya pada anak-anak, remaja, maupun orang tua (Benita, 2012). Gastritis merupakan penyakit yang disebabkanoleh infeksi bakteri Helicobacter pylori. Penggunaan obat golongan NSAID jangka panjang menyebabkan gastritis (Ehrlich, 2011). Gastritis merupakan masalah yang masih sangat banyak ditemukan di lingkungan masyarakat (Putri, 2010). Penyakit gastritis biasa dikenal dengan penyakit maag.

Gastritis merupakan peradangan pada lambung yang diakibatkan faktor iritasi, infeksi, pola makan yang tidak teratur dan tidak menjaga pola makan seperti makanan pedas, mengkonsumsi protein tinggi, kebiasaan mengkonsumsi makanmakanan pedas, dan minum kopi terlalu berlebihan (Herman, 2004). Penyakit ini mengganggu aktivitas sehari-hari, baik bagi remaja maupun orang dewasa dan menimbulkan bahaya seperti rusaknya fungsi lambung sehingga sampai pada tahap kanker lambung sampai menyebabkan kematian (Saydam, 2011). Gastritis dapat terjadi tiba-tiba (gastritis akut) atau secara bertahap (gastritis kronis). Penyakit tersebut mengakibatkan nyeri di ulu hati. (Ehrlich, 2011).

Prevalensi gastritis pada rawat inap di rumah sakit sebanyak 30.154 kasus menurut Departemen Kesehatan Republik Indonesia tahun 2012. Angka kejadian gastritis pada beberapa daerah di Indonesia cukup tinggi dengan prevalensi 274.396 kasus dari 238.452.952 jiwa penduduk. Sedangkan di Jawa Tengah angka kejadian gastritis sebesar 79,6\%. Gastritis di bedakan menjadi 2 yaitu gastritis akut dan kronik. Gastritis akut adalah peradangan yang terjadi di mukosa lambung yang disebabkan stress, alcohol, obat-obatan, bahan kimia yang terdapat di makanan (Suyono, 2001). Gastritis kronik menyebabkan inflamasi pada mukosa lambung yang bersifat menahun. Penyebab umumnya ialah infeksi Helicobacter pylori, dapat diatasi dengan memberantas ataupun menghambat Helicobacter pylori di dalam tubuh dengan meminum kombinasi dari obat-obatan (Omeprazole, Clarithromycin dan Amoxicillin) (Muttaqin, 2011).

Gastritis dapat di obati menggunakan Cimetidine, Sucralfate atau Omeprazole. (Muttaqin 2011). Tujuan utama dalam pengobatan ialah menghilangkan rasa nyeri dan digunakan untuk menekan faktor agresif dan memperkuat faktor defensive dengan cara mengurangi asam lambung dengan menetralkan asam lambung dan mengurangi sekresi asam lambung. Pemakaian obat yang tidak sesuai standart dapat menyebabkan kerugian pasien. terapi yang gagal disebabkan oleh ketidaktepatan dosis maupun terdapat interaksi obat yang digunakan dengan obat lain (Aridha, 2007).

\section{METODE PENELITIAN}

Metode deskriptif merupakan metode riset yang bertujuan untuk menjelaskan suatu peristiwa yang sedang berlangsung pada masa sekarang dan juga pada masa lampau. Metode riset ini dapat dibagi menjadi dua yaitu Longitudinal (sepanjang waktu) dan Cross Sectional (waktu tertentu). Metode ini digunakan untuk mengetahui efektifitas Penggunaan obat gastritis pada pasien rawat inap di Rumah Sakit Grand Med Lubuk Pakam.

\section{HASIL DAN PEMBAHASAN}




\section{Deskripsi Data}

Pada penelitian ini data diperoleh dengan mencatat penggunanan obat gastritis dari bulan Januari - Mei 2019 di Rumah Sakit GrandMed Lubuk Pakam.

\section{Data demografi}

a. Jenis kelamin

Berdasarkan penelitian yang dilakukan terhadap Evaluasi Penggunaan Obat Gastritis di Rumah Sakit Grandmed Lubuk Pakam Tahun 2020 diperoleh gambaran penggunaan obat Gastritis.

Tabel 4.2 Distribusi Jenis Kelamin Pasien Gastritis Di Rumah Sakit Grandmed Lubuk Pakam Periode Januari 2019 S/D Mei 2019

\begin{tabular}{lccc}
\hline No & $\begin{array}{c}\text { Jenis } \\
\text { Kelamin }\end{array}$ & Frekuensi & $\begin{array}{c}\text { Presentase } \\
(\%) \\
(\mathrm{n}=64 \%)\end{array}$ \\
\hline 1 & Laki-Laki & 20 & $31,2 \%$ \\
2 & Perempuan & 44 & $68,8 \%$ \\
& TOTAL & 64 & $100.0 \%$ \\
\hline & Berdasarkan & Dari & Tabel 4.2
\end{tabular}

jumlah pasien pengguna obat Gastritis di Rumah Sakit Grandmed Lubuk Pakam Tahun 2020 sebanyak 64 pasien. Untuk pasien laki-laki berjumlah 20 Pasien $(31,2 \%)$. kemudian untuk pasien perempuan berjumlah 44 pasien $(68,8$ $\%)$. Prevalensi ini menyimpulkan bahwa jumlah penderita berjenis kelamin perempuan lebih banyak daripada lakilaki. Hal ini terlihat dari persentase pasien perempuan $(68,8 \%)$ sedangkan Laki-laki $(31,2 \%)$.

b. Usia pasien

Berdasarkan penelitian yang dilakukan terhadap Evaluasi Penggunaan Obat gastritis Di Rumah Sakit Grandmed Lubuk Pakam diperoleh gambaran distribusi penggunaan obat Gastritis. Berdasarkan Usia Pasien Dapat Dilihat Pada Tabel 4.2.2 Dibawah Ini :

Tabel 4.2 Distribusi Usia Pasien pengguna obat Gastritis Di Rumah Sakit
Lubuk Pakam Pada Periode Januari 2019 S/D Mei 2019.

\begin{tabular}{lccc}
\hline NO & $\begin{array}{c}\text { Karakt } \\
\text { eristik }\end{array}$ & $\begin{array}{c}\text { Frekue } \\
\text { nsi }\end{array}$ & $\begin{array}{c}\text { Persentase } \\
(\%) \\
(\mathrm{n}=64 \%)\end{array}$ \\
\hline 1 & $\begin{array}{l}15-30 \\
\text { Tahun }\end{array}$ & 19 & $29,7 \%$ \\
2 & $\begin{array}{l}31-60 \\
\text { Tahun }\end{array}$ & 45 & $70,3 \%$ \\
\multicolumn{3}{c}{ Total } & \multicolumn{3}{c}{ Pada Tabel 4.2 dapat dijelaskan } \\
\hline \multicolumn{3}{c}{ untuk karakteristik pasien } \\
berdasarkan Gastritis \\
distribusi
\end{tabular}

digolongkan dalam 2 variasi kelompok, yaitu 15-30 Tahun, Pasien 31-60 Tahun. Jumlah terbanyak berada pada usia rentang 31-60 tahun yaitu 45 orang $(70,3 \%)$ sedangkan untuk 15-30 Tahun 19 orang $(29,7 \%)$.

\section{Karakteristik pasien analisis univariat}

\begin{tabular}{llcc}
\hline NO & $\begin{array}{l}\text { Pekerjaan } \\
\text { Responden }\end{array}$ & F & $\begin{array}{c}(\%) \\
(\mathrm{n}=64 \%)\end{array}$ \\
\hline 1 & Wiraswasta & 10 & $15,7 \%$ \\
2 & IRT & 26 & $40,7 \%$ \\
3 & Karyawan & 9 & $14,0 \%$ \\
4 & Petani & 3 & $4,6 \%$ \\
5 & Pelajar/Maha & 11 & $17,1 \%$ \\
& siswa & & \\
6 & PNS & 5 & $7,9 \%$ \\
& Total & 64 & $100.0 \%$ \\
\hline & Pada Tabel & 4.3 .1 & dapat
\end{tabular}

dijelaskan untuk karakteristik pasien Gastritis berdasarkan pekerjaan responden digolongkan dalam 6 variasi kelompok, yaitu Wiraswasta berjumlah 10 orang $(15,7 \%)$, IRT/Ibu rumah tangga berjumlah 26 orang $(40,7 \%)$, kemudian Karyawan berjumlah 9 orang $(14,0 \%)$, Petani 3 orang $(4,6 \%)$, Mahasiswa berjumlah 11 orang $(17,1$ $\%)$, dan PNS berjumlah 5 orang $(7,9$ $\%)$. Jumlah pekerjaan responden terbanyak berada pada pasien yang pekerjaan sebagai IRT/Ibu rumah tangga yaitu sebanyak $26(40,7 \%)$.

b. Agama responden 
Jurnal Farmasi, e-ISSN: 2655-0814

Vol. 3 No.2 Edisi November 2020-April 2021

http://ejournal.medistra.ac.id/index.php/JFM

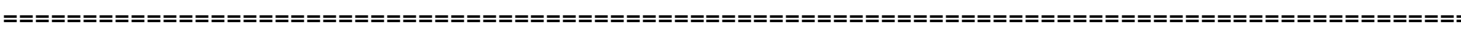

Received: 14 Januari 2021 :: Accepted: 21 Juni 2021 :: Published: 31 Oktober 2021

\begin{tabular}{clcc}
\hline NO & $\begin{array}{c}\text { Agama } \\
\text { Responden }\end{array}$ & F & $\begin{array}{c}\text { Persentas } \\
\text { e }(\%)\end{array}$ \\
\hline 1 & Islam & 38 & $59,4 \%$ \\
2 & Kristen & 26 & $40,6 \%$ \\
& & 64 & $100.0 \%$ \\
\hline \multirow{2}{*}{ Berdasarkan } & Tabel & 4.3 .2 \\
Karakteristik uji & chi-square
\end{tabular}

\begin{tabular}{cccc}
\hline 2 & OMEPRAZOLE & 18 & $28,1 \%$ \\
3 & RANITIDINE & 16 & $25 \%$ \\
TOTAL & 64 & $100 \%$ \\
\hline \multicolumn{3}{c}{ Pada Tabel 4.4 dijelaskan bahwa }
\end{tabular}

berdasarkan Agama Responden pada pasien Gastritis lebih banyak agama ISLAM yaitu berjumlah 38 orang (59.4\%).

C. Pendidikan terakhir

\begin{tabular}{clcr}
\hline NO & Pendididkan & F & \multicolumn{1}{c}{$(\%)$} \\
\hline 1 & Tidak & 8 & $12,5 \%$ \\
& Sekolah/ & & \\
& Tidak Tamat & & \\
& SD & & \\
2 & SD/SMP & 10 & $15,6 \%$ \\
3 & SMA/SMK & 43 & $67,2 \%$ \\
4 & Akademik/ & 3 & $4,7 \%$ \\
& Perguruan & & \\
& Tinggi & & \\
& Total & 64 & $100.0 \%$ \\
\hline & Berdasarkan & Tabel & 4.3 .3
\end{tabular}

Karakteristik uji chi-square berdasarkan Pendidikan Terakhir Responden pada pasien Gastritis lebih banyak pendidikan SMA yaitu berjumlah 43 orang $(67,2 \%)$.

Demografi penggunaan obat grastriris di RS. Grandmed Lubuk pakam

a. Jenis obat gastritis

Dari data penelitian yang dilakukan terhadap Evaluasi Penggunaan Obat Gastritis Rawat Inap di RS. Grandmed Lubuk Pakam pada periode Januari 2019 s/d Mei 2019, Berdasarkan Jenis Obat Gastritis Dapat Dilihat Pada Tabel Berikut :

Tabel 4.4 Penggunaan Obat Gastritis Berdasarkan Jenis Obat Gastritis Di Rumah Sakit Grandmed Lubuk Pakam.

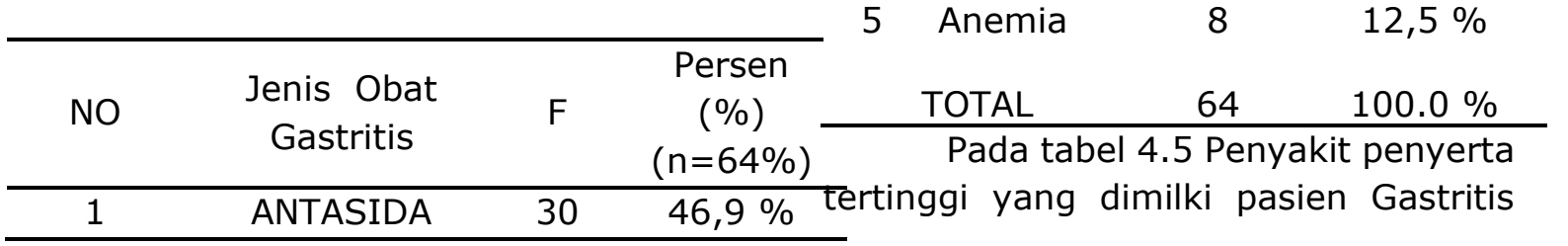


adalah penyakit Diare yaitu 20 pasien $(31,2 \%)$.

\section{Kerasionalan Penggunaan Obat Gastritis di Rumah Sakit Grandmed Lubuk Pakam Tahun 2020}

Evaluasi Kerasionalan Penggunaan

Obat Gastritis dilakukan terhadap 64 data rekam medik pasien yang menderita Gastritis di Rumah Sakit Grandmed Lubuk Pakam. Evaluasi kerasionalan dilakukan meliputi beberapa kriteria kerasionalan yaitu, Tepat Indikasi, Tepat Pasien, Tepat Obat, Tepat Dosis. Berdasarkan Hasil Penelitian Pada 64 Pasien Diketahui Kerasionalan Obat Gastritis Sebagai Berikut: ( Kemenkes RI, 2011)

a. Tepat indikasi

Pengobatan dikatakan tepat indikasi jika pemilihan dan pemberian obat berdasarkan diagnosis yang benar dengan keluhan yang dialami pasien. Indikasi juga dapat dilihat dari munculnya keluhan pasien yang biasa hadir pada pasien Gastritis seperti adanya gejala nyeri ulu hati, mual, muntah, hilang rasa nafsu makan. ( Kemenkes RI, 2011)

b. Tepat pasien

Pengobatan dikatakan tepat pasien jika pemberian pengobatan sesuai dengan patologis serta tidak menimbulkan masalah bila diberikan kepada pasien. Kriteria tepat pasien juga dilihat dari penyakit penyerta lain yang juga diderita oleh pasien dengan riwayat penyakit pasien. (Kemenkes RI, 2011)

\begin{tabular}{|c|c|c|c|}
\hline PASIEN & Ket & $\mathrm{F}$ & $\begin{array}{c}(\%) \\
(n=64)\end{array}$ \\
\hline $\begin{array}{l}\text { Tepat } \\
\text { Pasien }\end{array}$ & $\begin{array}{l}\text { Pemberian } \\
\text { Tidak } \\
\text { dikontarain } \\
\text { dikasi } \\
\text { karena } \\
\text { sesuai } \\
\text { dengan } \\
\text { usia, } \\
\text { riwayat }\end{array}$ & 64 & $100 \%$ \\
\hline
\end{tabular}

$$
\begin{aligned}
& \text { penyakit } \\
& \text { pasien. }
\end{aligned}
$$

Berdasarkan pada tabel 7. Ketepatan pada pasien Gastritis sebanyak 64 pasien (100\%).

c. Tepat obat

Pengobatan tepat obat adalah pemberian pengobatan kepada pasien merupakan obat pilihan pertama (drug of choice) sesuai dengan diagnosis penyakit penyakit, karakteristik pasien, gejala yang dialami pasien. Evaluasi yaitu sebanyak 64 pasien. ( Kemenkes $\mathrm{RI}, 2011$ )

\begin{tabular}{cccc}
\hline NO & $\begin{array}{c}\text { Ketepatan } \\
\text { Obat }\end{array}$ & F & $\begin{array}{c}\text { Presentas } \\
\text { e }(\%) \\
(\mathbf{n = 6 4 \% )}\end{array}$ \\
\hline $\mathbf{1}$ & Rasional & 62 & $96,9 \%$ \\
$\mathbf{2}$ & Irasional & 2 & $3,1 \%$ \\
& TotaL & 64 & $100.0 \%$ \\
\hline & Berdasarkan & pada & tabel 8.
\end{tabular}

Ketepatan Obat Rasional pada pasien Gastritis sebanyak 62 pasien $(96,9 \%)$. Dan Irasional 2 pasien $(3,1 \%)$.

d. Tepat dosis

Pengobatan tepat dosis adalah pemberian dosis yang telah sesuai dilihat dari parameter tepat dosis, frekuensi pemberian, rute pemberian serta durasi penggunaan obat. Jika pasien tidak memenuhi keempat kriteria tepat dosis tersebut, maka pasien tidak keempat ktiteria tepat dosis tersebut, maka pasien dinyatakan sebagai tidak tepat dosis. Kerasionalan tepat dosis di Rumah Sakit Grandmed Lubuk Pakam. ( Kemenkes RI, 2011).

\begin{tabular}{cccc}
\hline NO & $\begin{array}{c}\text { Ketepatan } \\
\text { Dosis }\end{array}$ & F & $\begin{array}{c}\text { Presentase } \\
(\%) \\
(\mathrm{n}=64)\end{array}$ \\
\hline 1 & Tepat Dosis & 64 & $100.0 \%$ \\
\hline
\end{tabular}


Berdasarkan Pada Tabel 9. Ketepatan Dosis Pada Pasien Gastritis Sebanyak 64 Pasien (100.0 \%).

\section{KESIMPULAN}

Berdasarkan kerasionalan obat Gastritis pada pasien Gstritis dengan meliputi 4 aspek yaitu tepat indikasi, tepat obat, tepat pasien, dan tepat dosis. Dari hasil penelitian yang didapatkan nilai presentase untuk tepat indikasi sebesar 96,9\%, tepat obat sebesar $96,9 \%$, tepat pasien $100 \%$, dan tepat dosis sebesar $100 \%$.

\section{DAFTAR PUSTAKA}

Aridha, N. 2007. Gambaran strain helicobacter pilory pada penderita gastritis kronis dan ulkus lambung, Bagian Ilmu Penyakit Dalam RSUP M.Djamil / Fakultas kedokteran Universitas Indonesia, Padang.

Benita, N.R. (2012). Pengaruh Penyuluhan Terhadap Tingkat Pengetahuan Kesehatan Reproduksi Pada Remaja Siswa Smp Kristen Gergaji. Karya Tulis Ilmiah. Program Pendidikan Sarjana Kedokteran. Fakultas Kedokteran

Departemen Kesehatan Republik Indonesia. 2009. Sistem Kesehatan Nasional. Jakarta

Dipiro, J.T, Robert, L.T, Gary, C.Y, Gary, R.M., Barbara, G.W, Michael Posey, 2008, Pharmacotherapy;A pathophysiological approach, Seventh Edition, Mc Graw Hill Companie

Ehrlich,S.D.2011. Articles gastritis. Fakultas Farmasi Universitas Gajah Mada.

Herman, R.B, 2004. Fisiologi Pencernaan Untuk Kedokteran, Andalas University Press, Padang.

Mutaqqin A. 2011. Gangguan Gastrointestinal Medika Bedah. Jakarta: Salemba Medika

Prince, Sylvia A., Lorraine McCarty Wilson. 2005. Patofisiologi :
Konsep Klinis Proses-Proses

Penyakit. Jakarta.

Putri, R.S.M., H. Agustin \& Wulansari. (2010). Hubungan Pola Makan Dengan Timbulnya Gastritis Pada Pasien Di Universitas Muhammadiyah Malang Unit Medical Center (UMC). JURNAL KEPERAWATAN, (JKEP). VOL , 1(2)., 156-164.

Saydam. 2011. Memahami Berbagai Penyakit (Penyakit Pernapasan dan Gangguan Pencernaasn). Bandung.

Suyono, Slamet. 2001. Buku Ajar IImu Penyakit Dalam. Jakarta: Balai Penerbitan 